\title{
Pengaruh Senam Hipertensi terhadap Tekanan Darah pada Komunitas Lansia Desa Petir Kecamatan Kalibagor, Banyumas
}

\author{
The Effect of Exercise on Blood Pressure in the Elderly Community in Petir \\ Village, Kalibagor District, Banyumas
}

\author{
Samudra Prihatin Hendra Basuki ${ }^{1}$, Sarwito Rahmad Barnawi ${ }^{2}$ \\ ${ }^{1,2}$ Keperawatan S1, Universitas Muhammadiyah Purwokerto \\ ${ }^{1}$ corr-author: hendra4edu@gmail.com
}

\begin{abstract}
ABSTRAK
Hipertensi merupakan penyakit penyebab kematian pertama di dunia. Penyakit ini juga merupakan jalan pembuka bagi penyakit-penyakit lainnya seperti jantung, gagal ginjal, dan stroke. Lansia di Indonesia pada umumnya sebagian besar adalah pengidap hipertensi. Kajian di lapangan menemukan kasus terbanyak pada lansia adalah hipertensi baru disusul penyakit-penyakit lainnya seperti diabetes, asam urat, rematik. Senam hipertensi digunakan sebagai media penurun hipertensi lansia pada penelitian ini. Tujuan dari penelitian ini adalah untuk mengetahui pengaruh senam hipertensi pada tekanan darah lansia baik sistol maupun diastol. Penelitian ini merupakan kuantitatif eksperimental dengan memberikan perlakuan senam kepada sampel penelitian. Perubahan tekanan darah diukur dengan menggunakan alat Sphygmomanometer air raksa. Hasil penelitian menunjukan bahwa Senam hipertensi memberi pengaruh terhadap penurunan tekanan darah sistolik dibuktikan dengan $\mathrm{P}$ value sebesar 0,002 dimana $\mathrm{P}-$ Value $<0,05$ pada komunitas lansia perempuan desa Petir kecamatan Kalibagor, Banyumas. Ada pengaruh penurunanan tekanan darah diastolik sebelum dan sesudah diberikan treatment senam selama tiga kali pada lansia perempuan desa Petir kecamatan Kalibagor, Banyumas.
\end{abstract}

Kata-kata kunci: senam hipertensi, hipertensi lansia, penurunan tekanan darah

\begin{abstract}
Hypertension is the first cause of death in the world. This disease is also an opening path for other diseases such as heart disease, kidney failure, and stroke. Most of the elderly in Indonesia are people with hypertension. The study in the field found that most cases in the elderly were new hypertension followed by other diseases such as diabetes, gout, rheumatism. Hypertension gymnastics is used as a medium to reduce hypertension in the elderly in this study. The purpose of this study was to determine the effect of hypertension exercise on elderly blood pressure, both systole, and diastole. This research is quantitative experimental by giving gymnastic treatment to the research sample. Changes in blood pressure were measured using a mercury Sphygmomanometer. The results showed that there was a significant decrease in both systolic and diastolic blood pressure after three times of hypertension exercise.
\end{abstract}

Keywords: Hypertension gymnastics, elderly hypertension, decreasing blood pressure 


\section{PENDAHULUAN}

Penyakit kardiovaskuler seperti jantung dan pembuluh darah adalah masalah kesehatan serius di dunia. Hipertensi menduduki rangking pertama penyebab kematian setiap tahunnya, dan merupakan pintu masuk penyakit jantung, gagal ginjal, diabetes dan stroke. Faktor risiko kematian tertinggi dialami laki-laki perokok, hipertensi dan diabetes. Menurut Badan Penyelenggara Jaminan Sosial (BPJS) menyebutkan bahwa biaya pelayanan hipertensi meningkat setiap tahunnya yaitu pada 2016 sebesar 2,8 triliun rupiah dan tahun 2017 dan 2018 meningkat masing-masing menjadi 3 triliun rupiah.

Sekitar 1,13 miliar orang di dunia adalah penderita hipertensi dan angka ini terus meningkat setiap tahunnya seiring dengan gaya hidup tidak sehat dan konsumsi makanan cepat saji tinggi kolesterol. Sebagian besar pengidap hipertensi ditemui di negara berkembang termasuk Indonesia. Hipertensi disebut sebagai the silent killer karena sering tanpa keluhan, sehingga penderita tidak mengetahui dirinya mempunyai penyakit hipertensi dan baru diketahui setelah terjadi komplikasi. Kerusakan organ akibat komplikasi akan tergantung kepada besarnya peningkatan tekanan darah dan lamanya waktu tanpa pengobatan.

Departemen kesehatan RI menyebutkan bahwa seseorang dikatakan lanjut usia dari usia 55 tahun keatas. Hasil proyeksi penduduk 2010-2035, periode lansia (aging), dimana $10 \%$ penduduk akan berusia 60 tahun keatas ditahun 2020 akan dialami Indonesia. Tingginya Usia Harapan Hidup (UUH) merupakan salah satu indikator capaian dari pembangunan nasional di bidang kesehatan ( Kemenkes RI, 2016).

Penduduk lanjut usia (lansia) di Indonesia dari tahun ke tahun jumlahnya terus meningkat. Menurut Kantor Kementerian Koordinator Kesejahteraan Rakyat (KESRA) menyebutkan, jika tahun 1980 usia harapan hidup (UHH) 52,2 tahun dan jumlah lansia 7.998 .543 orang $(5,54 \%)$ maka pada tahun 2006 menjadi 19 juta orang $(8,90 \%)$ dan UHH juga meningkat (66,2 tahun). Pada tahun 2010 penduduk lansia mencapai 23,9 juta atau 9,77\% dan UHH sekitar 67,4 tahun. Sepuluh tahun kemudian atau pada 2020 perkiraan penduduk lansia di Indonesia mencapai 28,8 juta atau $11,34 \%$ dengan UHH sekitar 71,1 tahun (Kusumowardani, 2014).

Penduduk lanjut usia ( $>60$ tahun) di Jawa Tengah sendiri mencapai $12,59 \%$ dari sekitar 34 juta total penduduk. Jumlah tersebut merupakan tertinggi kedua setelah Yogyakarta (13,81 persen). (Kementrian Kesehatan, 2017). Hipertensi adalah penyakit terbanyak pada usia lanjut, berdasarkan hasil Riset Kesehatan Dasar pada 2013. Dengan prevalensi $45,9 \%$ pada usia 55-64 tahun, 57,6\% pada usia $65,74 \%$ dan $63,8 \%$ pada usia kurang lebih 75 tahun (Infodatin Kemenkes RI, 2016).

Salah satu cara pemeliharaan kesegaran jasmani dengan melakukan senam ,karena dapat merangsang aktifitas kerja jantung untuk melakukan perubahan yang menguntungkan dalam tubuh seseorang yang melaksanakannya. Hal ini merupakan usaha preventif/pencegahan, tujuannya untuk meningkatkan jumlah interaksi oksigen yang diproses di dalam tubuh dalam waktu tertentu. Tujuan dari senam hipertensi adalah; melebarkan pembuluh darah, tahanan pembuluh darah menurunun, berkurangnya hormon yang memacu peningkatan tekanan darah, menurunkan lemak kolesterol yang tinggi.

Manfaat senam hipertensi adalah sebagai berikut; meningkatkan daya tahan jantung dan paru-paru serta membakar lemak yang berlebihan di tubuh karena aktifitas gerak untuk menguatkan dan membentuk otot dan beberapa bagian tubuh lainnya, seperti: pinggang, paha, pinggul, perut dan lain-lain. Kedua meningkatkan kelenturan, keseimbangan koordinasi, kelincahan, daya tahan dan sanggup melakukan kegiatan-kegiatan atau olah raga lainnya.

Kondisi penderita hipertensi secara medis berbeda dengan orang sehat. Untuk itu, perlu senam yang juga dilakukan secara khusus. Latihannya harus bertahap dan tidak boleh 
memaksakan diri. Gerakan dengan intensitas ringan dapat dilakukan perlahan sesuai kemampuan. Cara melakukan gerakan senam hipertensi terbagi menjadi empat bagia yaitu pemanasan, gerakan inti, gerakan-gerakan kaki, dan pendinginan (Kusmana, 2006). Selain senam hipertensi, olahraga dan diet juga berpengaruh pada tekanan darah sistolik dan diastolik pada minggu kedua, keempat, keenam, dan kedelapan (Kamal, 2013)

Astari dkk (2013) melakukan penelitian menggunakan senam pada lansia hipertensi dan hasil menunjukan bahwa terjadi penurunan rata-rata tekanan darah sistolik 21,67 $\mathrm{mmHg}$ dan penurunan tekanan darah diastolik $12,50 \mathrm{mmHg}$. Pemberian senam lansia berpengaruh secara signifikan terhadap tekanan darah sistolik pada lansia dengan hipertensi.

Hernawan dan Rosyid (2017) dalam penelitiannya membandingkan nilai pre test yaitu sebelum dilakukan intevensi dan nilai post test yaitu setelah dilakukan intervensi. Tekanan darah responden sebelum pemberian intervensi senam hipertensi sebagian besar adalah prehypertension (39\%). Tekanan darah responden setelah pemberian intervensi senam hipertensi sebagian besar adalah prehypertension (46\%). Terdapat pengaruh senam hipertensi terhadap tekanan darah lansia di Panti Wredha Panjang Surakarta

Penelitian ini menggunakan sampel lansia pengidap hipertensi. Berbeda dengan penelitian-penelitian yang sudah dilakukan sebelumnya dengan metode yang beragam, pendekatan yang dilakukan dalam penelitian ini dengan memberikan treatment senam hipertensi untuk menurunkan tekanan darah baik sistolik maupun diastol. Hasil akan diukur setelah lansia mengikuti senam hipertensi sebanyak tiga kali dengan jeda 7 hari setiap kegiatan senam. Tujuan dari penelitian ini adalah untuk mengetahui pengaruh senam hipertensi tehadap penurunan tekanan darah dengan cara membandingkan sistol pre-test dengan sistol post test dan membandingkan diastol pre-test dengan diastol post-test.

\section{METODE PENELITIAN}

Alur penelitian ini terdiri dari beberapa tahap, yaitu tahap persiapan, tahap pelaksanaan, tahap analisis data, dan tahap penarikan kesimpulan.

\section{Tahap Persiapan}

Pada tahap ini dilakukan survey pendahuluan dan identifikasi masalah. Survey tersebut menggunakan instrumen Kuesioner Format Survey Kesehatan Masyarakat Model A1. Dalam instrumen survey tersebut menggali data tentang:

\section{a. Struktur dan sifat keluarga}

Struktur dan Sifat Keluarga didalamnya mengumpulkan data tentang Identitas keluarga dan pola pemenuhan sehari-hari.

\section{b. Rumah dan lingkungan}

Rumah dan lingkungan menggali data terkait kesehatan dan kepemilikan rumah, sarana memasak, sampah, sumber air, jamban keluarga, saluran pembuangan air limbah dan kandang ternak.

\section{c. Riwayat kesehatan keluarga}

Riwayat kesehatan keluarga mengumpulkan data tentang; riwayat kesehatan anggota keluarga dan kebiasaan pemeriksaan kesehatan.

\section{d. Kesehatan ibu dan anak}

Kesehatan ibu dan anak terkait dengan kehamilan, post persalinan dan anak.

\section{e. Kesehatan lansia}

Kesehatan lansia terkait dengan keluhan fisik dan penyakit kronis lanisa. 


\section{f. Pelayanan kesehatan dan sosial}

Pelayanan kesehatan dan sosial mengggali data tentang jenis pelayanan kesehatan, tanggapan keluarga tentang petugas kesehatan, kunjungan petugas kesehatan puskesmas ke rumah dan posyandu.

Setelah dilakukan survey pendahuluan menggunakan Format Survey Kesehatan Masyarakat - Model A1, ditemukan masalah yang mayoritas diderita oleh warga desa petir terutama pada tingginya angka hipertensi yang mencapai 52\% warga lansia Dusun II, Desa Petir.

\section{Tahap Pelaksanaan}

Tahap pelaksanaan dilakukan aktifitas pengambilan data dan penentuan populasi dan sampel. Data primer diambil langsung dari lapangan dengan sebelumnya meminta izin kepada pihak terkait. Selain itu juga berkoordinasi dengan bidan desa dan kader kesehatan. Pengambilan data menggunakan Sphygmomanometer air raksa dan stethoscope yang sebelumnya sudah dikalibrasi untuk memastikan keakuratan dalam proses pengambilan data. Dibutuhkan 4 orang petugas, 2 orang sebagai pemandu senam hipertensi dan 2 orang bertugas mengukur dan mencatat tekanan darah lansia sistol dan diastole menggunakan alat Sphygmomanometer. Populasi pada penelitian ini adalah seluruh lansia dibawah binaan Posyandu lansia Desa Petir Kecamatan Kalibagor, Banyumas yang aktif mengikuti kegiatan sejumlah 45 orang lansia. Teknik Non Probability-Sampling digunakan dalam pengumpulan sampel dengan purposive-sampling terpilih sejumlah 25 lansia hipertensi berjenis kelamin perempuan.

Desain penelitian ini merupakan kuantitatif pre-eksperimen dengan one-group pretest-posttest design dimana mengukur perbandingan antara sebelum dan sesudah diberikan treatment berupa senam hipertensi. Pre-test dilakukan dengan cara melakukan pengukuran tekanan darah terhadap sample sebelum diberikan treatment. Selanjutnya, treatmen diberikan kepada sampel berupa senam hipertensi. Senam ini dilakukan selam tiga jam setiap sesi, dan dilakukan sebanyak tiga kali dengan jeda waktu tujuh hari disetiap sesi. Dibantu oleh kader kesehatan dalam pelaksanaan kegiatan senam pada pagi hari pukul 08.00-11.00 WIB kemudian setelahnya dilakukan pengukuran tekanan darah. Setelah dilakukan tiga kali senam hipertensi maka diukur lagi tekanan darahnya, hasil pengukuran tekanan darah tersebut dijadikan sebagai post-test dan dibandingkan dengan hasil pengukuran darah sebelum diberikan treatment senam hipertensi.

\section{Tahap Analisis Data}

Data penelitian dianalisis menggunakan penilaian distribusi data secara analitis dengan menggunakan Uji Kolmogorov-Smirnov (sampel >50) atau Shapiro-Wilk $(<50)$. Selanjutnya dilakukan statistik menggunakan Uji Wilcoxon untuk membandingkan dan mengetahui signifikansi data tekanan darah pre-test sistole dengan post tes-sistol dan membandingkan pre-test diastole dengan post-test diastole.

\section{Tahap Penarikan Kesimpulan}

Setelah semua proses dilalui dari awal pengumpulan data, anilasa data menggunakan serangkaian uji statistik dalam beberapa tahap, dan pembahasan maka ditariklah kesimpulan dari penelitian ini menjadi beberapa poin penting. 


\section{HASIL DAN PEMBAHASAN}

Pengukuran sistol dan diastol pre-test dan post-test menggunakan alat Sphygmomanometer disajikan dalam Tabel 1.

Tabel 1. Pengukuran tekanan darah 25 sampel penelitian setelah mengikuti senam hipertensi

\begin{tabular}{|c|c|c|c|c|}
\hline $\begin{array}{c}\text { Sampel } \\
\text { (lansia } \\
\text { hipertensi) }\end{array}$ & $\begin{array}{l}\text { Tekanan Darah } \\
\text { (mmHg) sebelum } \\
\text { mengikuti senam } \\
\text { (pre-test) }\end{array}$ & $\begin{array}{c}\text { Tekanan Darah } \\
\text { (mmHg) Senam } \\
\text { ke- } 1\end{array}$ & $\begin{array}{c}\text { Tekanan } \\
\text { Darah } \\
\text { (mmHg) } \\
\text { Senam ke-2 }\end{array}$ & $\begin{array}{c}\text { Tekanan Darah } \\
\text { (mmHg) Senam } \\
\text { ke-3 } \\
\text { (post-test) }\end{array}$ \\
\hline Lansia 1 & $150 / 90$ & $130 / 88$ & $140 / 90$ & $130 / 80$ \\
\hline Lansia 2 & $150 / 80$ & $140 / 90$ & $130 / 70$ & $120 / 80$ \\
\hline Lansia 3 & $140 / 80$ & $142 / 70$ & $130 / 80$ & $120 / 80$ \\
\hline Lansia 4 & $145 / 85$ & $148 / 80$ & $120 / 80$ & $110 / 70$ \\
\hline Lansia 5 & $135 / 75$ & $130 / 70$ & $130 / 80$ & $120 / 80$ \\
\hline Lansia 6 & $140 / 95$ & $140 / 100$ & $130 / 80$ & $120 / 80$ \\
\hline Lansia 7 & $145 / 85$ & $120 / 80$ & $120 / 60$ & $100 / 80$ \\
\hline Lansia 8 & $130 / 90$ & $130 / 90$ & $130 / 90$ & $120 / 80$ \\
\hline Lansia 9 & $190 / 100$ & $190 / 90$ & $160 / 80$ & $100 / 80$ \\
\hline Lansia 10 & $140 / 80$ & $144 / 77$ & $130 / 80$ & $130 / 80$ \\
\hline Lansia 11 & $143 / 90$ & $110 / 70$ & $130 / 80$ & $120 / 90$ \\
\hline Lansia 12 & $150 / 90$ & $160 / 90$ & $150 / 90$ & $120 / 90$ \\
\hline Lansia 13 & $142 / 87$ & $140 / 90$ & $130 / 70$ & $110 / 70$ \\
\hline Lansia 14 & $140 / 90$ & $140 / 90$ & $140 / 80$ & $100 / 80$ \\
\hline Lansia 15 & $150 / 90$ & $160 / 90$ & $140 / 90$ & $150 / 90$ \\
\hline Lansia 16 & $150 / 85$ & $140 / 80$ & $140 / 80$ & $110 / 90$ \\
\hline Lansia 17 & $145 / 90$ & $110 / 80$ & $140 / 90$ & $110 / 90$ \\
\hline Lansia 18 & $130 / 90$ & $120 / 70$ & $120 / 80$ & $110 / 70$ \\
\hline Lansia 19 & $150 / 90$ & $150 / 90$ & $120 / 80$ & $130 / 80$ \\
\hline Lansia 20 & $130 / 90$ & $120 / 80$ & $150 / 80$ & $130 / 80$ \\
\hline Lansia 21 & $180 / 100$ & $180 / 100$ & $180 / 100$ & $110 / 70$ \\
\hline Lansia 22 & $140 / 90$ & $140 / 90$ & $130 / 80$ & $110 / 80$ \\
\hline Lansia 23 & $150 / 90$ & $150 / 80$ & $140 / 80$ & $130 / 70$ \\
\hline Lansia 24 & $140 / 80$ & $110 / 60$ & $120 / 80$ & $120 / 90$ \\
\hline Lansia 25 & $150 / 90$ & $160 / 100$ & $130 / 70$ & $180 / 90$ \\
\hline
\end{tabular}

Pada Tabel 1 menunjukkan pengukuran 25 sampel yang semuanya berjenis kelamin perempuan, penelitian terhadap tekanan darah baik sistol maupun diastol pre-test dan posttest. Dimana diberikan tiga kali treatmen senam. Hasil penelitian menunjukkan bahwa sebelum diberikan treatment senam tekanan darah sistolik tertinggi adalah $190 \mathrm{mmHg}$, diastol tertinggi $100 \mathrm{mmHg}$, dimana rata-rata sistol adalah $145 \mathrm{mmHg}$ dan rata-rata diastol $120 \mathrm{mmHg}$ (Tabel 2).

Tabel 2. Hasil uji normalitas

\begin{tabular}{lcccccc}
\hline & \multicolumn{3}{c}{ Kolmogorov-Smirnov(a) } & \multicolumn{3}{c}{ Shapiro-Wilk } \\
\cline { 2 - 7 } & Statistic & df & Sig. & Statistic & df & Sig. \\
\hline Pre_sistol &, 309 & 25 &, 000 &, 764 & 25 &, 000 \\
post_sistol &, 229 & 25 &, 002 &, 807 & 25 &, 000 \\
pre_diastol &, 267 & 25 &, 000 &, 881 & 25 &, 007 \\
post_diastol &, 265 & 25 &, 000 &, 808 & 25 &, 000 \\
\hline
\end{tabular}

(Pengaruh Senam Hipertensi...... Samudra Prihatin Hendra Basuki, Sarwito Rahmad Barnawi) 
Penilaian distribusi data secara analitis dengan menggunakan Uji KolmogorovSmirnov (sampel $>50$ ) atau Shapiro-Wilk $(<50)$. Diperoleh nilai $p$ value $<0,05$ yang berarti bahwa data tidak berdistribusi normal, maka selanjutnya digunakanlah Uji Wilcoxon. (Sopiyudin, 2019) (Tabel 3).

Tabel 3. Hasil Uji Wilcoxon pre sistol post sistol

\begin{tabular}{lcccccc}
\hline & n & Min & Max & Median & P value & $\mathbf{Z}$ \\
\hline pre_sistol & 25 & 130 & 190 & 145 & 0,0001 & 3,802 \\
post_sistol & 25 & 100 & 180 & 90 & & \\
\hline
\end{tabular}

Berdasarkan hasil uji statistik data tekanan darah sistolik dengan menggunakan uji wilcoxon di dapatkan $\mathrm{P}$ value sebesar 0,001 dimana P-Value <0,05. Dapat disimpulkan bahwa senam hipertensi memberikan pengaruh terhadap penurunanan tekanan darah sistolik pre-test dan post-test pada komunitas lansia hipertensi. Hal ini sejalan dengan hasil penelitian Susilowati (2020) yang menyatakan bahwa senam lansia memiliki pengaruh signifikan terhadap tekanan darah lansia yang mengalami hipertensi pada kelompok prolanis Puskesmas Padasuka Cimahi (Tabel 4).

Tabel 4. Hasil Uji Wilcoxon pre-diastol post-diastol

\begin{tabular}{lcccccc}
\hline & n & Min & Max & Median & P value & Z \\
\hline pre_diastol & 25 & 75 & 100 & 120 & 0,002 & 3,129 \\
post_diastol & 25 & 70 & 90 & 80 & & \\
\hline
\end{tabular}

Pada data tekanan darah diastolik, berdasarkan hasil uji statistik dengan menggunakan uji wilcoxon di dapatkan $\mathrm{p}$ value sebesar 0,002 dimana P-Value $<0,05$ dapat disimpulkan bahwa ada pengaruh penurunanan tekanan darah diastolik sebelum dan sesudah diberikan treatment senam. Sejalan dengan penelitian Meyi (2021) bahwa terdapat pengaruh senam lansia terhadap tekanan darah sistolik dan diastolik pada lansia hipertensi di Kelurahan Dadok Tunggul Hitam Wilayah Kerja Puskesmas Dadok Tunggul Hitam Kota Padang.

\section{KESIMPULAN DAN SARAN}

Kesimpulan dari penelitian ini adalah: 1) senam hipertensi memberi pengaruh terhadap penurunan tekanan darah sistolik dibuktikan dengan $P$ value sebesar 0,002 dimana P-Value $<0,05$ pada komunitas lansia perempuan desa Petir kecamatan Kalibagor, Banyumas; 2) ada pengaruh penurunanan tekanan darah diastolik sebelum dan sesudah diberikan treatment senam selama tiga kali pada lansia perempuan desa Petir kecamatan Kalibagor, Banyumas. Sebagai saran yang disampaikan adalah perlu dilakukannya penelitian selanjutnya pada lansia laki-laki.

\section{UCAPAN TERIMA KASIH}

Terimakasih kepada Lembaga Penelitian dan Pengabdian Masyarakat Universitas Muhammadiyah Purwokerto, Tim Keperawatan Komunitas, Program Profesi Ners, Fakultas Ilmu Kesehatan Universitas Muhammadiyah Purwokerto atas program pembinaan lansia Desa Petir Kecamatan Kalibagor, Banyumas sehingga penelitian ini bisa dilaksanakan. 


\section{DAFTAR PUSTAKA}

Astari dkk. (2013). The Effect Of Gymnastics In The Elderly To The Elderly Blood Pressure With Hypertension In Ederly Gymnastic Group In Banjar Kaja Sesetan Denpasar Selatan. Coping: Community of Publishing in Nursing, Vol.1, No.1.

Bompa TO. (1994). Theory and Methodology of Training The Key to Athletic Performance. 2nd Edition, Iowa: Kendall/Hunt Publishing Company.

doi: 10.33757/jik.v5i1.361.g154

Hernawan, Totok., Fahrun Nur Rosyid. (2017). Pengaruh Senam Hipertensi Lansia Terhadap Penurunan Tekanan Darah Lansia dengan Hipertensi di Panti Wreda Darma Bhakti Kelurahan Pajang Surakarta, Jurnal Kesehatan, Vol. 10, No. 1. https://doi.org/10.23917/jk.v10i1.5489.

John MF Adam. (2006). Obesitas dan Sindroma Metabolik. Makassar: Fakultas Kedokteran Universitas Hasanuddin.

Kamal, M., Kusmana, D., Hardinsyah, H., Setiawan, B., \& Damanik, R. M. (2013). Pengaruh Olahraga Jalan Cepat dan Diet terhadap Tekanan Darah Penderita Prahipertensi Pria. Kesmas: Jurnal Kesehatan Masyarakat Nasional (National Public Health Journal), 7(6), 279-283.

Kemenkes.go.id. (2019, 17 Mei). Hipertensi Penyakit Paling Banyak Diidap Masyarakat. Diakses pada 20 Oktober 2020, dari https://www.kemkes.go.id/article/view/19051700002/hipertensi-penyakit-palingbanyak-diidap-masyarakat.html

Kusmana, Dede. (2006). Olahraga Untuk Orang Sehat dan Penderita Penyakit Jantung. Jakarta: Balai Penerbit Fakultas Kedokteran Universitas Indonesia.

Susilowati. 2020. Pengaruh Senam Lansia Terhadap Tekanan Darah Pada Lansia Yang Mengalami Hipertensi Di Kelompok Prolanis Wilayah Puskesmas Padasuka Cimahi Tahun 2018. Jurnal Kesehatan Kartika Vol.15 http://ejournal.stikesjayc.id/index.php/litkartika/article/view/119 Diakses 3 Juni 2021. 20.28.

Yanti, Meyi. (2021). Senam Lansia terhadap Tekanan Darah pada Lansia Hipertensi. JIK (Jurnal Ilmu Kesehatan) | April, 2021 Volume 5 No. 1. 